\title{
Effect of Diets Containing Dried Taro (Colocasia esculanta) Waste and Dried Yeast (Saccharomyces cerevisiae) on Performance of Growing Rabbits
} Amany A. Khayyal ${ }^{1}$; E. O. A. Bakr ${ }^{2}$; Y. L. Phillip ${ }^{1}$; A. M. Hussein ${ }^{1}$ and A. A. Khir ${ }^{1}$

${ }^{1}$ Animal Production Research Institute, Agricultural Research Center, Ministry of Agriculture, Dokki, Giza, Egypt.

2 Department of Animal Production, Faculty of Environmental Agricultural Sciences, Suez Canal University, El-Arish, North Sinai, Egypt.

\section{ABSTRACT}

A total of hundred and four New Zealand White (NZW) rabbits were chosen after weaned at 6 weeks of age and randomly divided into 8 equal groups (13 rabbits/ group) according to their initial live body weight $(804.31 \pm 20 \mathrm{~g})$, to evaluate the utilization of dried taro waste (TW) without or with dried yeast (DY) in feeding growing rabbits and their response on growth performance, nutrients digestibility, carcass traits, some blood parameters, cecum activity as well as economic efficiency. Rabbits were fed ad-libitum on diets containing $0.0,7.5,15,22.5 \%$ TW without supplement for groups G1, G3, G5 and G7, respectively and the other groups (G2, G4, G6 and G8) were fed the same levels of TW, with $0.5 \%$ DY. At the end of the experimental period (14 weeks of age), digestibility trials were carried out to determine the digestibility of feed nutrients and the feeding values of the experimental diets. In addition, four rabbits were slaughtered from each group to test the carcass traits, some blood parameters and cecum activity. The experimental diets were fed to growing rabbits for 8 weeks post-weaning period. Results revealed that the TW contained $2479 \mathrm{Kcal}$ digestible energy $/ \mathrm{Kg}, 16.41 \%$ crude protein, $14.30 \%$ crude fiber, $7.42 \%$ ether extract, $16.92 \%$ ash, $1.22 \%$ calcium $0.27 \%$ phosphorus on DM basis, and some antinutritional factor such as calcium oxalate $(0.56 \%)$. Formulation of rabbit diets with different levels of TW $(0.0,7.5,15$ and $22.5 \%)$ without or with $0.5 \%$ DY showed no significant differences $(\mathrm{P}>0.05)$ among the dietary treatments in respect of live body weight and total weight gain at different ages (6-14 weeks). It was also clear that the insignificant highest weight gain was associated with rabbits fed diets containing DY (G2, G4 and G6) during 6-14 weeks of age than those fed the un-supplemented diets. Total feed intake of TWdiets was slightly decreased during the whole experimental period with G3 and G5, but significant decreased with G7 compared to that of control diet (G1). Supplemented DY with rabbit diets tended to improve total feed intake at 6-10 and 6-14 weeks of age comparing with the non-supplemented ones. Feed conversion and performance index didn't affected significantly by dietary treatments. In comparison with control diet, most nutrient digestibilities of most tested diets did not affected significantly. Almostly carcass traits (empty carcass, edible giblets, non-edible parts and dressing percentage) did not affected significantly by most tested treatments compared with control diet. TW or DY had slightly changes on blood constituents of experimental rabbits. Insignificantly higher concentrations of TVFA's and ammonia-N were observed in the cecum contents of rabbits fed on the different levels of TW without or with DY compared with the control group. Similarly each of cecum weight and $\mathrm{pH}$ of cecum content were not significant changed by all tested rations based on control one. Profitability and economic efficiency were markedly improved with TW-diets without or with DY compared with control diet.In conclusion dried taro waste could be used in feeding of growing rabbits up to $22.5 \%$ without or with dried yeast with no adverse effect on productive performance, carcass traits, physiological function and economical efficiency.

Keywords: Rabbits, taro waste, yeast, productive performance, digestibility, carcass traits, blood parameters, cecum activity, economical efficiency

\section{INTRODUCTION}

Egypt faces an acute problem of inadequate quality and quantity of animal feeds, especially during the summer. Therefore, efforts have been made towards the solution of feed shortage by exploring and improving more unconventional feeds. Minimizing the feed cost could be achieved through the use of untraditional cheaper feed ingredients or improving utilization of common feeds by using some feed additives. Vegetable residues are the plant materials that remained after harvesting of vegetable crops. Most of them are beneficially used as organic fertilizers or burned causing environmental pollution, but some are dried and stored as forage sources for ruminants or they may be left in the field as grazing for livestock (Renard, 2001). Taro (Colocasia esculenta) has high yield and most its varieties contain an irritating or acrid agent and cannot be eaten in fresh state. The cultivated area of taro was 6545 feddans, which gave a yield of 102563 tons, according to Ministry of Agriculture (2016). Taro by-product can be a potentially working as a protein source for animals, especially pigs due to its good nutritional quality where the leaves having (DM basis): $25 \% \mathrm{CP}, 12.1 \% \mathrm{CF}, 10.7 \% \mathrm{EE}, 1.74 \% \mathrm{Ca}$, and $0.58 \% \mathrm{P}$ (FAO, 1993), in addition rich in vitamins and minerals like thiamin, riboflavin, iron, phosphorus, zinc, vitamin B6, vitamin $\mathrm{C}$, niacin, potassium, copper and manganese (Wikipedia, the free encyclopedia http:/en. wikipedia.org/wiki/Taro). The anti-nutritional factors in taro cocoyam including oxalates, phytates, tannins and saponins were found by (Agwunobi et al., 2002). Dried yeast (Saccharomyces cerevisiae) supplementation inhibits harmful bacteria, alter microbial metabolism and decrease intestinal $\mathrm{pH}$ and therefore potentially used as probiotics, which can enhance animal and poultry production (Makled, 1991; Miles and Bootwella, 1991). Stanley et al. (1993) attributed the beneficial effect of yeast to its effectiveness in counteracting aflatoxins or reducing aflatoxicosis in the small intestine. Onifade et al. (1999) studied the effects of dietary supplementation with a pure culture of Saccharomyces cerevisiae up to $3.0 \mathrm{~g} / \mathrm{kg}$ on growth performance, blood composition and clinical enzyme activities in serum of rabbits. They found that yeast addition significantly improved growth performance, reduced serum cholesterol and maintained the serum enzymes at normal ranges. Yeast addition increased nutritional value of poor quality forages, improved feed intake and milk yield in dairy cows (Jouany and Morgavi, 2007). There are a number of roles in which micro-organism play an either positive or negative effect in food processing. The positive aspects are generally regarding the part of the fermentation processing which namely related to product preservation, flavor development, reduction of anti-nutrients and improving protein and fibre digestibility (Ojokoh, 2007). Many studies have indicated that the use of yeast products as feed supplements may have a significant impact on the 
performance of domestic animals (Bakory, 2014). The effect of yeast on growth performance and health status varies depending on the dose, age, livestock conditions, and even between studies. However, yeast's mechanism of action remains unknown (Belhassen et al., 2016).

The objective of this study was to investigate the effective inclusion of dried taro waste as nonconventional feed ingredient in rabbit diets without and with dried yeast on growth performance, digestibility of nutrients, carcass traits, and some blood parameters.

\section{MATERIALS AND METHODS}

This experiment was carried out during the period from March to May 2016 (for 8 weeks) at Department of Animal Production, Faculty of Environmental Agricultural Sciences, Suez Canal University, El-Arish, North Sinai, Egypt, and the laboratories works were carried out at Animal Production Research Institute (APRI), Agriculture Research Center (ARC), Ministry of Agriculture, Dokki, Giza, Egypt. An ample amount of dried taro waste (TW) which included leaves and petioles (false stems)) was provided by Menofiya Governorate, while dried yeast (DY) was provided by Egyptian Sugar Company and Integrated Industries, Hawamdia, Giza, Egypt.

Dried TW was collected directly after harvest their fruits and chopped to $2-3 \mathrm{~cm}$ pieces with moisture content of $90 \%$ approximately, then sun-air dried for 14 days, then completely ground before mixing with the other ingredients and stored in bags until use. Samples of the feed ingredients were analyzed for crude protein (CP), crude fiber $(\mathrm{CF})$, ether extract (EE) and ash. Minerals (calcium and total phosphorus) were determined in other samples which ashed in an oven at $600^{\circ} \mathrm{C}$ for 2 hours; digested with $\mathrm{HCl} 50 \%$ concentration in boiling water bath and then diluted with water to $100 \mathrm{ml}$. Minerals were determined using atomic absorption. Anti-nutritional factor (total oxalate) was determined using the method of Ukpabi and Ejidoh (1989). Proximate analysis was performed according to A.O.A.C. methods (1996). Ingredient and calculated chemical composition of the experimental diets are presented in Table 1. Also, chemical analysis of dried TW and DY are presented in Table 2.

Table 1. Ingredients and calculated chemical composition of the experimental diets (as fed).

\begin{tabular}{|c|c|c|c|c|c|c|c|c|}
\hline \multirow{2}{*}{ Item } & \multicolumn{8}{|c|}{ Experimental diets \% } \\
\hline & G1 & G2 & G3 & G4 & G5 & G6 & G7 & G8 \\
\hline Ingredients (\%): & & & & & & & & \\
\hline Alfalfa hay $(12 \% \mathrm{CP})$ & 30.00 & 30.00 & 27.00 & 27.00 & 24.00 & 24.00 & 22.00 & 22.00 \\
\hline Yellow corn & 10.00 & 10.40 & 10.00 & 10.35 & 10.00 & 10.00 & 10.00 & 10.00 \\
\hline Barley & 17.60 & 17.40 & 14.00 & 13.60 & 10.10 & 10.20 & 6.70 & 7.85 \\
\hline Soybean meal ( $44 \% \mathrm{CP})$ & 16.90 & 16.20 & 16.00 & 15.55 & 15.40 & 14.80 & 14.80 & 14.45 \\
\hline Wheat bran & 20.00 & 20.00 & 20.00 & 20.00 & 20.00 & 20.00 & 18.50 & 17.20 \\
\hline Dried taro waste & - & - & 7.50 & 7.50 & 15.00 & 15.00 & 22.50 & 22.50 \\
\hline Dried yeast & - & 0.50 & - & 0.50 & - & 0.50 & - & 0.50 \\
\hline Molasses & 3.00 & 3.00 & 3.00 & 3.00 & 3.00 & 3.00 & 3.00 & 3.00 \\
\hline DL-Methionine & 0.10 & 0.10 & 0.10 & 0.10 & 0.10 & 0.10 & 0.10 & 0.10 \\
\hline Vitamins\& minerals mixture ${ }^{1}$ & 0.50 & 0.50 & 0.50 & 0.50 & 0.50 & 0.50 & 0.50 & 0.50 \\
\hline 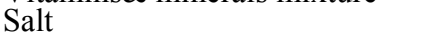 & 0.50 & 0.50 & 0.50 & 0.50 & 0.50 & 0.50 & 0.50 & 0.50 \\
\hline Limestone & 1.05 & 1.05 & 1.05 & 1.05 & 1.05 & 1.05 & 1.05 & 1.05 \\
\hline Di-Calcium phosphate & 0.35 & 0.35 & 0.35 & 0.35 & 0.35 & 0.35 & 0.35 & 0.35 \\
\hline Total & 100 & 100 & 100 & 100 & 100 & 100 & 100 & 100 \\
\hline Calculated analysis ${ }^{2}$ : & & & & & & & & \\
\hline Dry matter (DM), \% & 87.17 & 87.19 & 87.27 & 87.29 & 87.38 & 87.40 & 87.50 & 87.52 \\
\hline Organic matter (OM), \% & 81.39 & 81.43 & 80.86 & 80.79 & 80.11 & 80.14 & 79.47 & 79.54 \\
\hline Crude protein (CP), $\%$ & 17.09 & 17.00 & 17.01 & 17.00 & 17.03 & 17.00 & 17.01 & 17.01 \\
\hline Ether extract (EE), \% & 2.42 & 2.42 & 2.77 & 2.77 & 3.12 & 3.12 & 3.44 & 3.41 \\
\hline Nitrogen free extract (NFE), \% & 48.34 & 48.52 & 47.62 & 47.70 & 46.79 & 46.90 & 45.88 & 46.09 \\
\hline Ash, $\%$ & 5.78 & 5.76 & 6.52 & 6.51 & 7.27 & 7.26 & 8.03 & 7.98 \\
\hline Digestible energy $(\mathrm{DE})^{3}, \mathrm{kcal} / \mathrm{kg}$ & 2515 & 2500 & 2515 & 2500 & 2515 & 2500 & 2510 & 2500 \\
\hline Crude fiber $(\mathrm{CF}), \%$ & 13.54 & 13.49 & 13.35 & 13.31 & 13.17 & 13.13 & 13.14 & 13.03 \\
\hline NDF, $\%$ & 37.82 & 37.79 & 37.70 & 37.67 & 37.57 & 37.55 & 37.56 & 37.49 \\
\hline ADF, $\%$ & 21.78 & 21.74 & 21.61 & 21.57 & 21.44 & 21.40 & 21.42 & 21.32 \\
\hline Hemicellulose, \% & 16.04 & 16.05 & 16.09 & 16.10 & 16.14 & 16.15 & 16.14 & 16.17 \\
\hline Calcium, \% & 1. 01 & 1.01 & 1.05 & 1.05 & 1.10 & 1.10 & 1.16 & 1.15 \\
\hline Total phosphorus, $\%$ & 0.52 & 0.52 & 0.51 & 0.52 & 0.51 & 0.51 & 0.50 & 0.50 \\
\hline nine, $\%$ & 0.36 & 0.36 & 0.35 & 0.34 & 0.33 & 0.33 & 0.31 & 0.31 \\
\hline Lysine, \% & 0.82 & 0.80 & 0.76 & 0.74 & 0.71 & 0.69 & 0.66 & 0.65 \\
\hline DE:CP & 147.18 & 147.08 & 147.81 & 147.02 & 147.64 & 147.06 & 147.55 & 147.00 \\
\hline
\end{tabular}

1-Supplied per Kg. of diet: 12000 IU Vit. A; 2200 IU D3; 10mg Vit. E; 2.0 mg Vit.K3; 1.0 mg Vit. B1; 4.0 mg Vit. B2; 1.5 mg Vit. B6; 0.0010mg Vit. B12; 6.7 mg Vit. Pantothenic acid;6.67 mg Vit. B5; 1.07mg Biotin; $1.67 \mathrm{mg}$ Folic acid; $400 \mathrm{mg}$ Choline chloride; $22.3 \mathrm{mg}$ $\mathrm{Zn} ; 10 \mathrm{mg} \mathrm{Mn} ; 25 \mathrm{mg} \mathrm{Fe} ; 1.67 \mathrm{mg} \mathrm{Cu} ; 0.25 \mathrm{mg} \mathrm{I} ; 0.033 \mathrm{mg}$ Se and $133.4 \mathrm{mg}$ Mg.l.

2-According to MOA (2001).

3-Calculated according to Cheeke (1987): DE $(\mathrm{Kcal} / \mathrm{g})=4.36-0.0491(\% \mathrm{NDF}) . \% \mathrm{NDF}=28.924+0.657(\% \mathrm{CF}) . \% \mathrm{ADF}=9.432+0.912$ $(\% \mathrm{CF})$. Hemicellulose $=\% \mathrm{NDF}-\%$ ADF .

G1: group that fed the basal diet (control), G2: group that fed the basal diet with dried yeast (0.5\%), G3, G5 and G7: groups that fed the basal diet with dried taro waste $(7.5,15$ and $22.5 \%$ ), while G4, G6 and G8: groups that fed the basal diet with the same percentages of dried taro waste and with dried yeast $(0.5 \%)$.

\section{Experimental design and management:}

Hundred and four New Zealand White (NZW)

rabbits were chosen after weaned at 6 weeks of age and divided into 8 similar groups (13 rabbits/ group) according to their initial live body weight $(804.31 \pm 20 \mathrm{~g})$. The experimental period, extended from 6 to 14 weeks of age. Rabbit groups G1 (control), G3, G5 and G7 were fed their diets included TW at rate of $0,7.5,15$ and $22.5 \%$, respectively. The same previous rates of TW with $0.5 \%$ DY were offered to rabbit groups G2, G4, G6 and G8, 
respectively to evaluate the utilization of dried taro waste (TW) without or with dried yeast (DY) in feeding growing rabbits. The experimental diets were formulated to be isonitrogenous $(\sim 17 \% \mathrm{CP})$ and iso-caloric $(\sim 2500 \mathrm{Kcal}$ $\mathrm{DE} / \mathrm{Kg}$ diet). All diets were pelleted and contained adequate levels of nutrients to satisfy the nutrients requirements of growing rabbits according to Agriculture Ministry Decree (1996). Rabbits of each group were housed in galvanized wire batteries in a well-ventilated building (natural through the window) and offered the experimental pelleted diets ad libitum. Fresh water was available at all times from automatic drinkers with nipples for each cage. Urine and feces dropped from cages on the floor were cleaned every day in the morning. All rabbits were observed daily, kept under the same managerial, hygienic and environmental conditions, and vaccinated against common diseases. All rabbits were individually weighed at the beginning of the experiment, then weekly before offering the morning meal until marketing age (14 weeks). Feed intake was weekly recorded during the experimental period. Live body weight, weight gain, feed intake, feed conversion ( $\mathrm{g}$ feed $\mathrm{g}$ gain), performance index $\%$ (final live body weight $(\mathrm{Kg}) /$ feed conversion*100) according to North (1981) and economic efficiency were estimated.

Digestibility trials:

At the end of the growth experimental period (14 weeks of age), digestibility trials were carried out to determine the nutrient digestibilities and feeding values of the experimental diets. A total number of 24 male rabbits were taken randomly ( 3 within each treatment) and allotted in different treatments. Rabbits were housed individually in metabolic cage to facilitate the collection of all droppings throughout the digestibility trials. The same feeding regime used during the feeding trial was also followed during the digestibility trials. Feed intake was daily recorded and quantitative collection of feces was started 24 hours after offering the daily feed. Feces of each rabbit were collected every day in the morning for a collection period of 5 days, sprayed with $2 \%$ boric acid for trapping any ammonia released, then oven dried at $60 \mathrm{oC}$ till constant weight, finely ground and stored for chemical analysis. Diets and feces were analyzed according to A.O.A.C. (1996). Digestion coefficients of nutrients and feeding values were calculated according to Abou-Raya (1967).

Carcass traits:

At the end of feeding trial (14 weeks of age), four rabbits representing each dietary treatment were randomly taken to evaluate the carcass traits. Rabbits were fasted for approximately 12 hours and individually weighed to record the pre-slaughter weight. After complete bleeding and skinning, the empty carcass with head, liver, kidneys and heart were weighed separately according to Cheeke (1987). Individual blood samples (from the same slaughtered rabbits) were collected in dry clean centrifuge tubes containing few drops of heparin solution and centrifuged at 3000 r.p.m for 20 minutes to separate blood plasma, and then stored in deep freezer at approximately $-20 \mathrm{oC} \pm 1$ until the time of analysis to estimate blood parameters. Various chemical analyses were conducted using commercial kits and measuring the optical density by spectrophotometer, following the same steps as described by manufactures.

\section{Cecum activity:}

Samples of cecum contents were taken individually from the four animals of each treatment at the end of the experimental period after being fasted for $12 \mathrm{hrs}$. Cecum fluid samples were obtained after rabbits slaughtered and then strained through four folds of gauze and divided into three portions. The first portion was used immediately for the estimation $\mathrm{pH}$ of cecum contents by using $\mathrm{pH}$ meter and the second portion was used immediately for estimation of ammonia nitrogen concentration by applying Conway (1958), while the third portion was preserved by addition of $1 \mathrm{ml} \mathrm{N} / 10 \mathrm{HCL}$ and $2 \mathrm{ml}$ orthophosphoric acid to each $2 \mathrm{ml}$ of cecum contents juice for determination of total volatile fatty acids (TVFA's) according to Eadie et al. (1967).

\section{Economic efficiency:}

Economic efficiency was calculated as the ratio between incomes price of weight gain and the cost of feed consumed over 6-14 weeks of age.

\section{Statistical analysis:}

Data were analyzed for all variables using the general linear models procedure to establish the differences between means using SAS software version 9.1 (SAS Institute, 2004). The model used was: $\mathbf{Y i j}=\boldsymbol{\mu}+\mathbf{T i}+\mathbf{e i j}$ Where: $\mathrm{Yij}=$ the observation of $\mathrm{ij} . \mu=$ the overall mean. $\mathrm{T} i=$ the effect of $i$ (treatments). eij $=$ the experimental random error.

Data of percentages were subjected to arc-sin transformation to approximate normal distribution before being analyzed. Variables having a significant F- test were compared using Duncan's multiple rang test (Duncan, 1955). All statements of statistical significance were based on probability $(\mathrm{P}<0.05)$.

\section{RESULTS AND DISCUSSION}

Chemical analysis of dried taro waste (TW), taro leaves, false stems and dried yeast (DY):

Chemical analysis of TW, taro leaves, petioles (false stems) and DY (on DM basis) are presented in Table (2). The TW was contained 16.41, 7.42, 14.30, 44.95 and $16.92 \%$ for CP, EE, CF, NFE and ash, respectively. The corresponding values for taro leaves were $24.32,7.15$, $13.60,40.33$ and $14.96 \%$ and for false stems were 7.01 , $6.24,16.08,51.10$ and $19.57 \%$. Concentrations of calcium and phosphorus of TW were 1.22 and $0.27 \%$, respectively being slightly higher than those of taro leaves and markedly lower than those of taro false stems. Dried yeast had high contents of CP, NFE and P, otherwise it had low contents of $\mathrm{EE}, \mathrm{CF}$ and $\mathrm{Ca}$. The present values are within the range that reported by Ngo Huu Toan and Preston, 2010, Nguyen Tuyet Giang et al., 2010 and Du Thanh Hang et al., 2014. Also, the concentration of total oxalate were recorded $0.56,0.45$ and $0.60 \%$ in TW, leaves and petioles (false stems), respectively. Dahlgren and Savage (2007) showed that younger taro leaves contained a mean of $5.89 \mathrm{~g}$ total oxalate $\mathrm{kg}-1$ fresh weight compared to 4.43 $\mathrm{g}$ total oxalate $\mathrm{kg}-1$ fresh weight for mature leaves grown in a greenhouse. Generally, it is obvious that TW and DY are rich in most nutrients and other bio-compounds and could be used as a valuable ingredient (TW) or as an excellent feed additive (DY) in rabbit diets.

\section{Productive performance:}

Data presented in Table (3) showed that the inclusion of different levels of TW without or with DY in the diet of rabbits had no significant differences $(\mathrm{P}>0.05)$ among these 
dietary treatments in respect of live body weight and total weight gain at different ages (from 6-14 weeks). Slightly improvements were observed due to added DY into the TWdiets in the mentioned traits. These results are in agreement with those obtained by Belhassen et al. (2016) who reported that supplementation of feed with yeast $(1 \mathrm{~g} / \mathrm{kg}$ diet $)$ did not modify growth traits and resulted in only a temporary increase in weight gain after weaning rabbits. Total feed intake of diets contained the different levels of TW were significant $(\mathrm{P}>0.05)$ decreased during the experimental period (6-14weeks of age) and that might be due to the oxalate effect which is considerably working as a major factor contributing to the anti-palatability effect of taro waste (Ravindran et al., 1996 and Agwunobi et al., 2002). Hang and Preston (2010) suggested that ensiled taro leaves can replace up to $30 \%$ of the dietary fish meal and in diets of growing pigs without performance loss. Regarding feed conversion trait, results cleared that no significant effect due to the addition of different levels of TW either alone or with $0.5 \%$ DY into the diets of rabbits. It means that TW could be incorporated in the rabbits diets up to $22.5 \%$ without causing any adverse effect on the productive performance. Taro cocoyam meal could be effectively replaced maize at $25 \%$ (raw sundried) and 50\% (boiled sundried) as a major source of energy in diets of broiler finishers (Abdulrashid and
Agwunobi, 2009). On the other hand, TW-diets supplemented with $5 \mathrm{~g} / \mathrm{kg}$ diet significantly $(\mathrm{P}>0.05)$ increased total feed intake at 6-10 and 6-14 weeks of age comparing with the non-supplemented. In relation to these results, Bakory (2014) reported that DY had great ability to alter the metabolic activities of gastrointestinal bacteria which excessively improve the efficiency of feed utilization by providing more useful supply of nutrients to the animals for growth. Rabbits fed diets containing the different levels of TW without or with DY did not affected significantly on feed conversion and performance index at different ages. In disagreement with those results Agwunobi et al. (2002) indicating that feed conversion ratio decreased significantly $(\mathrm{P}<0.05)$ with increasing the level of taro cocoyam meal in the diets of pigs. This was due to the effects of antinutritional factors. Khanna, et al. (2014) reported that rabbits raised with $2 \%$ yeast supplementation had significantly $(\mathrm{P}<0.05)$ higher body weight gain than those raised without yeast supplementation. Also, Soliman et al. (2000) showed that rabbits fed on diet supplemented with yeast culture attained significantly higher final body weight, more daily weight gain and the best feed conversion efficiency. On the contrary, Fekete et al. (2001) reported that yeast at 300 and $600 \mathrm{mg} / \mathrm{kg}$ supplemented diet had no significant effect on growth performance in rabbits.

Table 2. Proximate chemical analysis (\%) of taro waste, taro leaves, petioles and yeast used in experimental diets (as DM).

\begin{tabular}{|c|c|c|c|c|}
\hline Item & Taro waste & Taro leaves & Petioles (false stems) & Yeast \\
\hline Dry matter (DM), \% & 90.09 & 90.76 & 90.46 & 91.20 \\
\hline Crude protein $(\mathrm{CP}), \%$ & 16.41 & 24.32 & 7.01 & 45.58 \\
\hline Ether extract (EE), \% & 7.42 & 7.15 & 6.24 & 0.44 \\
\hline Ash, \% & 16.92 & 14.96 & 19.57 & 5.90 \\
\hline Organic matter $(\mathrm{OM}), \%$ & 83.08 & 85.04 & 80.43 & 94.10 \\
\hline Nitrogen free extract (NFE), $\%$ & 44.95 & 40.33 & 51.10 & 47.66 \\
\hline $\mathrm{DE}(\mathrm{kcal} / \mathrm{kg})^{\mathrm{k}}$ & 2479 & 2501 & 2421 & 2926 \\
\hline Crude fiber (CF), \% & 14.30 & 13.60 & 16.08 & 0.43 \\
\hline Neutral detergent fiber (NDF) $1, \%$ & 38.32 & 37.86 & 39.49 & 29.20 \\
\hline Acid detergent fiber (ADF) ${ }^{\mathrm{m}}, \%$ & 22.47 & 21.84 & 24.10 & 9.82 \\
\hline Hemicellulose $^{\mathrm{n}}, \%$ & 15.85 & 16.02 & 15.39 & 19.38 \\
\hline Calcium $(\mathrm{Ca}), \%$ & 1.22 & 1.10 & 1.45 & 0.13 \\
\hline Total phosphorus $(\mathrm{P}), \%$ & 0.27 & 0.20 & 0.40 & 1.51 \\
\hline Total oxalate, $\%$ & 0.56 & 0.45 & 0.60 & - \\
\hline
\end{tabular}

k,l,m,n Calculated according to Cheeke (1987): $\quad$ DE $(\mathrm{Kcal} / \mathrm{g})=4.36-0.0491(\% \mathrm{NDF})$.

$\% \mathrm{NDF}=28.924+0.657(\% \mathrm{CF}) . \% \mathrm{ADF}=9.432+0.912(\% \mathrm{CF})$. Hemicellulose $=\% \mathrm{NDF}-\%$ ADF

Table 3. Productive performance as affected by dried taro waste and dried yeast in the experimental diets for growing NZW rabbits at different ages.

\begin{tabular}{|c|c|c|c|c|c|c|c|c|c|}
\hline \multirow{2}{*}{ Item } & \multicolumn{8}{|c|}{ Experimental diets } & \multirow{2}{*}{$\pm \mathbf{S E}$} \\
\hline & G1 & G2 & G3 & G4 & G5 & G6 & G7 & G8 & \\
\hline $\begin{array}{l}\text { Live body weight (g): } \\
\text { Initial (6weeks) } \\
10 \text { weeks } \\
14 \text { weeks }\end{array}$ & $\begin{array}{c}784.54 \\
1555.38 \\
2148.85\end{array}$ & $\begin{array}{c}801.23 \\
1556.92 \\
2198.00\end{array}$ & $\begin{array}{c}793.77 \\
1501.38 \\
2160.23\end{array}$ & $\begin{array}{c}799.62 \\
1588.00 \\
2170.85\end{array}$ & $\begin{array}{c}794.46 \\
1509.31 \\
2115.77\end{array}$ & $\begin{array}{c}804.31 \\
1526.46 \\
2137.69\end{array}$ & $\begin{array}{c}798.83 \\
1509.25 \\
2140.42\end{array}$ & $\begin{array}{c}787.77 \\
1441.77 \\
2068.54\end{array}$ & $\begin{array}{l} \pm 29.17 \\
\pm 51.95 \\
\pm 57.45\end{array}$ \\
\hline $\begin{array}{l}\text { Total weight gain }(\mathrm{g}) \text { : } \\
\text { 6-10 weeks } \\
\text { 10-14 weeks } \\
\text { 6-14 weeks }\end{array}$ & $\begin{array}{c}770.84 \\
593.47 \\
1364.31 \\
\end{array}$ & $\begin{array}{c}755.69 \\
641.08 \\
1396.77 \\
\end{array}$ & $\begin{array}{c}707.61 \\
658.85 \\
1366.46 \\
\end{array}$ & $\begin{array}{c}788.38 \\
582.85 \\
1371.23 \\
\end{array}$ & $\begin{array}{c}714.85 \\
606.46 \\
1321.31 \\
\end{array}$ & $\begin{array}{c}722.15 \\
611.23 \\
1333.38 \\
\end{array}$ & $\begin{array}{c}710.42 \\
631.17 \\
1341.59 \\
\end{array}$ & $\begin{array}{c}654.00 \\
626.77 \\
1280.77 \\
\end{array}$ & $\begin{array}{l} \pm 46.03 \\
\pm 34.55 \\
\pm 57.59\end{array}$ \\
\hline $\begin{array}{l}\text { Total feed intake(g): } \\
\text { 6-10 weeks } \\
10-14 \text { weeks } \\
6-14 \text { weeks } \\
\end{array}$ & $\begin{array}{l}2093.2^{\mathrm{a}} \\
3202.1^{\mathrm{c}} \\
5295.3^{\mathrm{b}}\end{array}$ & $\begin{array}{l}2100.1^{\mathrm{a}} \\
3235.9^{\mathrm{a}} \\
5336.0^{\mathrm{a}}\end{array}$ & $\begin{array}{l}2080.8^{\mathrm{b}} \\
3212.4^{\mathrm{bc}} \\
5293.2^{\mathrm{b}}\end{array}$ & $\begin{array}{r}2091.2^{\mathrm{a}} \\
3209.6^{\mathrm{bc}} \\
5300.8^{\mathrm{ab}}\end{array}$ & $\begin{array}{l}2055.2^{\mathrm{c}} \\
3229.8^{\mathrm{ab}} \\
5285.0^{\mathrm{bc}}\end{array}$ & $\begin{array}{r}2075.5^{\mathrm{b}} \\
3224.2^{\mathrm{ab}} \\
5299.7^{\mathrm{ab}}\end{array}$ & $\begin{array}{l}2050.4^{\mathrm{c}} \\
3216.2^{\mathrm{bc}} \\
5266.6^{\mathrm{c}}\end{array}$ & $\begin{array}{c}2057.1^{\mathrm{c}} \\
3218.4^{\mathrm{bc}} \\
5275.5^{\mathrm{c}}\end{array}$ & $\begin{array}{l} \pm 3.67 \\
\pm 4.88 \\
\pm 6.05\end{array}$ \\
\hline $\begin{array}{l}\text { Feed conversion ratio } \\
6-10 \text { weeks } \\
10-14 \text { weeks } \\
6-14 \text { weeks } \\
\end{array}$ & $\begin{array}{c}\text { g feed/g g } \\
2.72 \\
5.40 \\
3.88 \\
\end{array}$ & $\begin{array}{l}2.78 \\
5.05 \\
3.82 \\
\end{array}$ & $\begin{array}{l}2.94 \\
4.88 \\
3.87 \\
\end{array}$ & $\begin{array}{l}2.65 \\
5.51 \\
3.87 \\
\end{array}$ & $\begin{array}{l}2.88 \\
5.33 \\
4.00 \\
\end{array}$ & $\begin{array}{l}2.87 \\
5.27 \\
3.97 \\
\end{array}$ & $\begin{array}{l}2.89 \\
5.10 \\
3.93 \\
\end{array}$ & $\begin{array}{l}3.15 \\
5.13 \\
4.12 \\
\end{array}$ & $\begin{array}{l} \pm 0.272 \\
\pm 0.313 \\
\pm 0.186 \\
\end{array}$ \\
\hline $\begin{array}{l}\text { Performance index } \% \text { : } \\
\text { 6-10 weeks } \\
\text { 10-14weeks } \\
6-14 \text { weeks }\end{array}$ & $\begin{array}{l}57.28 \\
39.83 \\
55.36 \\
\end{array}$ & $\begin{array}{l}56.02 \\
43.55 \\
57.54 \\
\end{array}$ & $\begin{array}{l}51.06 \\
44.31 \\
55.77 \\
\end{array}$ & $\begin{array}{l}59.87 \\
39.42 \\
56.16 \\
\end{array}$ & $\begin{array}{l}39.73 \\
52.90 \\
\end{array}$ & $\begin{array}{l}53.11 \\
40.53 \\
53.78 \\
\end{array}$ & $\begin{array}{l}52.29 \\
42.01 \\
54.52 \\
\end{array}$ & $\begin{array}{l}45.84 \\
40.28 \\
50.22 \\
\end{array}$ & $\begin{array}{l} \pm 4.94 \\
\pm 3.01 \\
\pm 3.68 \\
\end{array}$ \\
\hline
\end{tabular}

a, $b$ and $c$ means in the same row with different superscripts are significantly $(P \leq 0.05)$ different. $\mathrm{SE}=$ standard error 
Digestibility and feeding values:

Chemical analysis of the experimental diets for growing NZW rabbits is presented in Table (4). Comparable values respecting the contents of $\mathrm{CP}, \mathrm{CF}, \mathrm{EE}$ and NFE were observed among the experimental diets. No significant differences were found among all experimental treatments for all digestibility coefficients except for G7 that mostly have the lowest values in digestibility of DM, $\mathrm{OM}, \mathrm{CF}$ and NFE and also TDN value (Table 5). Slightly improvements of $\mathrm{CP}, \mathrm{CF}, \mathrm{EE}$ digestions or DCP were observed due to added DY into the TW-diets in the mentioned traits compared with control diet (G1). The improvement of crude fiber digestibility may be due to an improvement of cecal microorganisms, which have a major effect on fiber digestion in rabbits (Fernandez et al., 1994). These results are in agreement with the findings of Ojokoh (2007) who reported that, micro-organism (yeast) play a key role of either positive or negative effect. The positive aspects are generally regarded as part of the fermentation processing-namely; product preservation, flavor development, reduction of anti-nutritional factors and enhances the nutrients, vitamins, essential amino acids (proteins) by improving protein and fiber digestibility. Increasing TW without or with DY supplement in rabbit diets decreased the digestibility coefficients that might be due to the oxalate effect which is considerably working as a major factor contributing to the anti-palatability effect of taro waste as recorded by Agwunobi et al., 2002. Furthermore, Abang and Shittu (2015) observed that antinutrients such as tannins, oxalates, phytates and saponin decreased with prolonged fermentation with microorganism such as fungus (Sacchoromyes cerevisiae) and improves fiber digestibility, boost protein content of peeled taro cocoyam meal (Colocasia esculenta var esculenta) and reduces the anti-nutritional factors to a more tolerable level. On the contrary, significant improvement in the digestibility of nutrients has been reported by Hammad and Gomaa (2001) and Abdou and Gomaa (2002) who supplemented the diets of rabbits with probiotic yeast culture.

Table 4. Chemical analysis (\%) of the experimental diets for growing NZW rabbits (as DM basis)

\begin{tabular}{lllllll}
\hline Experimental & DM OM & CP & CF & EE NFE Ash
\end{tabular}

$\begin{array}{lllllll}\text { diets } & & & & & & \\ \text { G1 } & 89.0793 .51 & 18.9814 .872 .86 & 56.806 .49\end{array}$

G2 $\quad 89.2093 .5418 .9714 .743 .0156 .826 .46$

G3 $\quad 89.6192 .7218 .8114 .813 .3655 .747 .28$

G4 89.3392.71 18.9314 .983 .4255 .387 .29

G5 $\quad 90.4091 .9618 .8714 .863 .1555 .088 .04$

G6 $\quad 90.7092 .0018 .9114 .963 .5654 .578 .00$

G7 $\quad 90.7991 .1518 .8614 .523 .6554 .128 .85$

G8 $\quad 90.3991 .1718 .8614 .653 .7353 .938 .83$

Table 5. Digestion coefficients of nutrients and feeding values as affected by dried taro waste and dried yeast in the experimental diets for growing NZW rabbits.

\begin{tabular}{|c|c|c|c|c|c|c|c|c|}
\hline \multirow{2}{*}{ Experimental diets } & \multicolumn{6}{|c|}{ Digestibility \% } & \multicolumn{2}{|c|}{ Feeding values \% } \\
\hline & DM & $\mathbf{O M}$ & $\mathbf{C P}$ & $\mathbf{C F}$ & $\mathbf{E E}$ & NFE & DCP & TDN \\
\hline$\overline{\mathrm{G} 1}$ & $67.87^{\mathrm{ab}}$ & $70.27^{\mathrm{ab}}$ & 64.90 & $39.76^{\mathrm{ab}}$ & 75.19 & $78.67^{\mathrm{a}}$ & 12.31 & $65.38^{\mathrm{a}}$ \\
\hline $\mathrm{G} 2$ & $67.33^{\mathrm{ab}}$ & $70.60^{\mathrm{ab}}$ & 70.63 & $41.34^{\mathrm{ab}}$ & 76.04 & $77.01^{\mathrm{ab}}$ & 13.40 & $66.03^{a}$ \\
\hline G3 & $65.76^{\mathrm{ab}}$ & $68.53^{\mathrm{ab}}$ & 65.42 & $37.29^{b}$ & 76.77 & $76.15^{\mathrm{ab}}$ & 12.31 & $63.64^{\mathrm{ab}}$ \\
\hline G4 & $71.28^{\mathrm{a}}$ & $73.72^{\mathrm{a}}$ & 68.67 & $50.36^{\mathrm{a}}$ & 79.75 & $80.03^{\mathrm{a}}$ & 13.00 & $67.98^{\mathrm{a}}$ \\
\hline G5 & $66.24^{\mathrm{ab}}$ & $68.48^{\mathrm{ab}}$ & 64.90 & $37.81^{\mathrm{b}}$ & 76.91 & $76.59^{\mathrm{ab}}$ & 12.25 & $63.34^{\mathrm{ab}}$ \\
\hline G6 & $68.20^{\mathrm{ab}}$ & $70.57^{\mathrm{ab}}$ & 68.32 & $40.56^{\mathrm{ab}}$ & 79.38 & $77.65^{\mathrm{a}}$ & 12.92 & $65.37^{\mathrm{a}}$ \\
\hline G7 & $61.84^{b}$ & $64.85^{\mathrm{b}}$ & 65.78 & $30.31^{\mathrm{b}}$ & 76.88 & $71.09^{\mathrm{b}}$ & 12.41 & $58.81^{\mathrm{b}}$ \\
\hline G8 & $65.89^{\mathrm{ab}}$ & $68.90^{\mathrm{ab}}$ & 68.34 & $38.95^{\mathrm{ab}}$ & 78.40 & $74.85^{\mathrm{ab}}$ & 12.89 & $62.78^{\mathrm{ab}}$ \\
\hline
\end{tabular}

a and $b$ means in the same column with different superscripts are significantly $(P \leq 0.05)$ different.

\section{Carcass traits:}

Commercial empty carcass weight and percentage were unaffected significantly by treatments (Table 6). Similar trend was observed among dietary treatments in respect of dressing percentage, with the highest values being occurred with G4 and G8. These results indicated that using TW at a rate of $22.5 \%$ without or with DY improved carcass traits which agreed with the findings of Olajide (2012). Concerning the edible giblets the differences among most experimental treatments did not significant respecting liver, kidney and heart (Table 7). These results coincide with the findings obtained by Soliman et al. (2000) and Ismail et al. (2004) who found that feeding yeast culture had no significant effect on carcass yield and components of growing rabbits. Paryard and Mahmoudi (2008) reported that yeast (Saccharomyces cerevisiae) supplement could improve the performance and decrease the weight of inedible offals. Khanna et al. (2014) also reported that rabbits raised with $2 \%$ yeast supplementation had significantly $(\mathrm{P}<0.05)$ decrease the inedible offal weights by improving the edible offal than the rabbits raised without yeast supplementation. Adejoro (2013) resulted that sundried wild taro cocoyam meal may be used in poultry ration at only about $10 \%$ inclusion with no significant differences in the overall carcass characteristics between the control diet and the varying levels of wild taro cocoyam meal which could be advisably inclusion up to $20 \%$ of broiler rations as a tolerable level.

\section{Blood parameters:}

Data presented in Table (8) showed no significant differences $(\mathrm{P}>0.05)$ due to either the level of TW or the addition of DY in respect of concentrations of total protein, albumin and globulin in the blood. The same effect was occurred among treatments in respect of AST, ALT, uric acid and creatinine contents, being non significant differences in its values. Also, no significant changes in the concentrations of $\mathrm{Ca}$ and cholesterol due to the addition of DY in TW diets of the rabbits, while Ca concentration was significant increased only with the high level of TW in the diet. Blood cholesterol concentration was significant decreased with G5 and G7 in comparison with control group (G1). The nonsignificant effects of dietary treatments on most serum metabolites may be due to the adequacy of nutrients especially CP. Excessively serum total protein and 
albumin have been reported to be directly responsive to protein intake and quality (Eggum, 1989 and Onifade and Abu, 1998). Decreased cholesterol may be due to linked to contents of saponins in TW. Saponins are known to bind with bile acids and cholesterol, thereby such compounds can be purge these fatty compounds from the body and consequently lowering the blood cholesterol level (Michael, 2005). Manal (2012) with broiler and Ismail et al. (2004) with rabbits supplemented their diets with yeast culture and found that blood plasma cholesterol level was reduced significantly. Moreover,
Onifade et al. (1999) reported that serum protein and albumin level increased and the serum levels of cholesterol, ALT and AST decreased with dietary yeast in rabbits. The differences in the enzymatic activity may be due to animal species and probiotic interventions. Paryard and Mahmoudi (2008) noted lower plasma cholesterol and triglyceride concentration and higher total plasma protein, albumin and globulin concentration in broiler chicks fed 1.5\% Saccharomyces cerevisiae.

Table 6. Carcass traits as affected by dried taro waste and dried yeast in the experimental diets for growing NZW rabbits.

\begin{tabular}{|c|c|c|c|c|c|c|c|c|c|}
\hline \multirow[t]{2}{*}{$\begin{array}{l}\text { Experimental } \\
\text { diets }\end{array}$} & \multirow{2}{*}{$\begin{array}{c}\begin{array}{c}\text { Pre-slaughter } \\
\text { weight (fasted) }\end{array} \\
\text { (g) }\end{array}$} & \multicolumn{2}{|c|}{$\begin{array}{l}\text { Empty } \\
\text { carcass }\end{array}$} & \multicolumn{2}{|c|}{$\begin{array}{c}\text { Dressing } \\
\text { (total edible parts) }\end{array}$} & \multicolumn{2}{|c|}{$\begin{array}{l}\text { Edible } \\
\text { giblets }\end{array}$} & \multicolumn{2}{|c|}{$\begin{array}{c}\text { Non-edible } \\
\text { parts }\end{array}$} \\
\hline & & (g) & $\%$ & (g) & $\%$ & (g) & $\%$ & (g) & $\%$ \\
\hline$\overline{\mathrm{G} 1}$ & 2093.75 & 1249.75 & 59.61 & 1332.10 & 63.54 & 82.36 & $3.93^{\mathrm{ab}}$ & $761.65^{\mathrm{ab}}$ & 36.46 \\
\hline $\mathrm{G} 2$ & 2210.00 & 1318.75 & 59.73 & 1408.85 & 63.81 & 90.10 & $4.08^{\mathrm{ab}}$ & $801.15^{\mathrm{ab}}$ & 36.19 \\
\hline G3 & 2196.25 & 1305.00 & 59.41 & 1398.94 & 63.68 & 93.94 & $4.27^{\mathrm{a}}$ & $797.31^{\mathrm{ab}}$ & 36.32 \\
\hline G4 & 22.83 .75 & 1385.00 & 60.62 & 1471.59 & 64.41 & 86.59 & $3.79^{\mathrm{ab}}$ & $812.16^{\mathrm{a}}$ & 35.59 \\
\hline G5 & 2078.75 & 1250.00 & 60.09 & 133681 & 64.23 & 86.81 & $4.15^{\mathrm{a}}$ & $741.94^{\mathrm{ab}}$ & 35.77 \\
\hline G6 & 2148.75 & 1300.00 & 60.46 & 1376.49 & 64.03 & 76.49 & $3.57^{\mathrm{b}}$ & $772.26^{\mathrm{ab}}$ & 35.97 \\
\hline G7 & 2090.00 & 1256.75 & 60.13 & 1339.66 & 64.10 & 82.91 & $3.96^{\mathrm{ab}}$ & $750.34^{\mathrm{ab}}$ & 35.90 \\
\hline G8 & 2035.00 & 1231.25 & 60.38 & 1315.09 & 64.45 & 83.84 & $4.07^{\mathrm{ab}}$ & $719.91^{b}$ & 35.55 \\
\hline$\pm \mathrm{SE}$ & \pm 83.90 & \pm 57.73 & & \pm 62.61 & & \pm 5.96 & & \pm 26.74 & \\
\hline
\end{tabular}

$a$ and $b$ means in the same column with different superscripts are significantly $(\mathrm{P} \leq 0.05)$ different. $\quad \mathrm{SE}=$ standard error

Total edible parts wt. $=$ Empty carcass wt. (with head) + edible giblets wt. $\quad$ Edible giblets wt. $=$ Liver + Kidneys wt. + Heart wt.

Total edible parts $\%=$ Total edible parts wt $/$ Fasted wt. $* 100$

Table 7. Carcass traits as affected by dried taro waste and dried yeast in the experimental diets for growing NZW rabbits.

\begin{tabular}{lcccccccccc}
\hline Experimental & \multicolumn{2}{c}{ Skin } & \multicolumn{2}{c}{ Head } & \multicolumn{2}{c}{ Liver } & \multicolumn{2}{c}{ Kidneys } & \multicolumn{2}{c}{ Heart } \\
\cline { 2 - 11 } diets & $\mathbf{( g )}$ & $\mathbf{\%}$ & $\mathbf{( g )}$ & $\mathbf{\%}$ & $\mathbf{( g )}$ & $\mathbf{\%}$ & $\mathbf{( g )}$ & $\mathbf{\%}$ & $\mathbf{( g )}$ & $\mathbf{\%}$ \\
\hline G1 & $261.25^{\mathrm{ab}}$ & $12.41^{\mathrm{ab}}$ & 120.17 & $5.73^{\mathrm{ab}}$ & 64.89 & $3.09^{\mathrm{ab}}$ & $11.71^{\mathrm{b}}$ & 0.560 & $5.76^{\mathrm{b}}$ & $0.275^{\mathrm{b}}$ \\
G2 & $280.00^{\mathrm{a}}$ & $12.64^{\mathrm{a}}$ & 124.23 & $5.63^{\mathrm{ab}}$ & 69.84 & $3.16^{\mathrm{ab}}$ & $12.63^{\mathrm{ab}}$ & 0.575 & $7.63^{\mathrm{a}}$ & $0.347^{\mathrm{a}}$ \\
$\mathrm{G} 3$ & $251.25^{\mathrm{ab}}$ & $11.43^{\mathrm{ab}}$ & 119.40 & $5.43^{\mathrm{b}}$ & 75.11 & $3.42^{\mathrm{a}}$ & $13.19^{\mathrm{ab}}$ & 0.600 & $5.65^{\mathrm{b}}$ & $0.257^{\mathrm{b}}$ \\
G4 & $260.00^{\mathrm{ab}}$ & $11.44^{\mathrm{ab}}$ & 127.85 & $5.61^{\mathrm{ab}}$ & 65.49 & $2.86^{\mathrm{ab}}$ & $14.76^{\mathrm{a}}$ & 0.648 & $6.34^{\mathrm{ab}}$ & $0.277^{\mathrm{b}}$ \\
G5 & $228.75^{\mathrm{b}}$ & $11.05^{\mathrm{b}}$ & 123.26 & $5.94^{\mathrm{ab}}$ & 67.76 & $3.23^{\mathrm{ab}}$ & $12.87^{\mathrm{ab}}$ & 0.621 & $6.18^{\mathrm{b}}$ & $0.296^{\mathrm{ab}}$ \\
G6 & $263.75^{\mathrm{ab}}$ & $12.30^{\mathrm{ab}}$ & 115.97 & $5.40^{\mathrm{b}}$ & 58.10 & $2.71^{\mathrm{b}}$ & $12.46^{\mathrm{ab}}$ & 0.583 & $5.94^{\mathrm{b}}$ & $0.278^{\mathrm{b}}$ \\
G7 & $228.50^{\mathrm{b}}$ & $10.93^{\mathrm{b}}$ & 125.84 & $6.02^{\mathrm{a}}$ & 63.93 & $3.06^{\mathrm{ab}}$ & $13.46^{\mathrm{ab}}$ & 0.643 & $5.52^{\mathrm{b}}$ & $0.264^{\mathrm{b}}$ \\
G8 & $233.75^{\mathrm{ab}}$ & $11.71^{\mathrm{ab}}$ & 117.85 & $5.83^{\mathrm{ab}}$ & 66.17 & $3.20^{\mathrm{ab}}$ & $12.39^{\mathrm{ab}}$ & 0.612 & $5.28^{\mathrm{b}}$ & $0.258^{\mathrm{b}}$ \\
$\pm \mathrm{SE}$ & \pm 14.54 & & \pm 5.17 & & \pm 5.50 & & \pm 0.784 & & \pm 0.450 & \\
\hline
\end{tabular}

a and $b$ means in the same column with different superscripts are significantly $(P \leq 0.05)$ different.

$\mathrm{SE}=$ standard error

${ }^{1}$ On relative to pre-slaughter weight (fasted weight).

Table 8. Some blood parameters as affected by dried taro waste and dried yeast in the experimental diets for growing NZW rabbits.

\begin{tabular}{|c|c|c|c|c|c|c|c|c|c|}
\hline \multirow{2}{*}{ Item } & \multicolumn{8}{|c|}{ Experimental diets } & \multirow{2}{*}{ \pm SE } \\
\hline & G1 & G2 & G3 & G4 & G5 & G6 & G7 & G8 & \\
\hline Cholesterol (g/dl) & $171.8^{\mathrm{a}}$ & $169.2^{\mathrm{ab}}$ & $168.4^{\mathrm{ab}}$ & $165.4^{\mathrm{bc}}$ & $164.2^{\mathrm{bc}}$ & $163.2^{\mathrm{c}}$ & $161.7^{\mathrm{c}}$ & $160.6^{\mathrm{c}}$ & \pm 1.55 \\
\hline Total protein $(\mathrm{g} / \mathrm{dl})$ & $5.84^{\mathrm{b}}$ & $5.91^{\mathrm{ab}}$ & $5.92^{\mathrm{ab}}$ & $5.96^{\mathrm{ab}}$ & $5.97^{\mathrm{ab}}$ & $5.97^{\mathrm{ab}}$ & $6.05^{\mathrm{ab}}$ & $6.13^{\mathrm{a}}$ & \pm 0.071 \\
\hline Albumin $(\mathrm{g} / \mathrm{dl})$ & 3.70 & 3.69 & 3.68 & 3.71 & 3.72 & 3.69 & 3.77 & 3.83 & \pm 0.122 \\
\hline Globulin (g/dl) & 2.14 & 2.22 & 2.23 & 2.25 & 2.26 & 2.27 & 2.28 & 2.30 & \pm 0.166 \\
\hline $\mathrm{A} / \mathrm{G}$ ratio $(\mathrm{g} / \mathrm{dl})$ & 1.73 & 1.73 & 1.65 & 1.73 & 1.67 & 1.63 & 1.66 & 1.68 & \pm 0.165 \\
\hline $\operatorname{AST}(\mathrm{U} / \mathrm{I})$ & 55.06 & 53.78 & 52.95 & 51.51 & 50.42 & 49.32 & 49.07 & 48.98 & \pm 2.02 \\
\hline $\operatorname{ALT}(\mathrm{U} / \mathrm{I})$ & 38.90 & 37.06 & 36.04 & 35.89 & 35.06 & 34.23 & 33.85 & 33.11 & \pm 1.82 \\
\hline Uric acid (mg/dl) & 4.32 & 4.30 & 4.31 & 4.28 & 4.26 & 4.23 & 4.20 & 4.13 & \pm 0.073 \\
\hline Creatinine $(\mathrm{mg} / \mathrm{dl})$ & 1.17 & 1.16 & 1.15 & 1.14 & 1.13 & 1.12 & 1.12 & 1.11 & \pm 0.040 \\
\hline Calcium (mg/dl) & $7.34^{c}$ & $7.38^{\mathrm{c}}$ & $7.42^{\mathrm{bc}}$ & $7.55^{\mathrm{bc}}$ & $7.66^{\mathrm{abc}}$ & $7.73^{\mathrm{ab}}$ & $7.88^{\mathrm{a}}$ & $7.94^{\mathrm{a}}$ & \pm 0.096 \\
\hline
\end{tabular}

a, $b$ and $c$ means in the same row with different superscripts are significantly $(P \leq 0.05)$ different.

$\mathrm{SE}=$ standard error

\section{Cecum activity:}

Cecum activity of the experimental diets for growing NZW rabbits is presented in Table (9). It could be shown that, insignificantly higher concentrations of TVFA's and ammonia-N were observed in the cecum contents of rabbits fed on the all tested diets than those of control group (G1). Also, the cecum weight and $\mathrm{pH}$ values were not affected by all tested diets in comparison with control (G1) diet. Based on the obtained results, it is concluded that TW or DY supplemented can safely be 
used as feed in growing rabbit diets with no adverse effects on growth performance, carcass traits or health condition. It is well known that TVFA's are the main products of microbial fermentation of carbohydrates; consequently, their concentration in the cecum and other fermentative areas can be used as an indirect estimation of microbial activity. In agreement with the present result, Hammad and Gomaa (2001) and Abdou and Gomaa (2002) reported that rabbits fed on yeast culture-supplemented diets had significantly higher caecal microbial contents. Also, Ismail, et al. (2004) reported that rabbits fed on yeast culture supplemented diets had significantly higher $(\mathrm{P} \leq 0.05)$ concentration of TVFA's while ammonia-N were significantly higher $(\mathrm{P} \leq 0.05)$ only for groups of rabbits fed on the highest level of yeast supplement $(1.5 \mathrm{~g} / \mathrm{kg}$ diet $)$ compared to that of the control group.

Economic efficiency:

Rabbits of G7 and G8 were found to have better economic efficiency (Table 10). The present results revealed that TW at the rate of $22.5 \%$ without or with DY supplemention $(0.5 \%)$ could be better as the feed cost/ kg gain compared with control diet (G1) and the other tested diets. Anigbogu (1996) showed that the use of taro meals at $12.5 \%$ yielded a better profit and had better rate of return on investment than the control that based on corn grains. Manal (2012) showed that the highest economic and relative economic efficiency values were obtained with the diet of $0.5 \%$ dry yeast. It may be due to the better feed conversion of birds received dry yeast and it is a good natural feed additive for improving performance of broiler chicks.

Table 9. Cecum activity as affected by dried taro waste and dried yeast in the experimental diets for growing NZW rabbits.

\begin{tabular}{llccc}
\hline \multirow{2}{*}{$\begin{array}{l}\text { Experimental } \\
\text { diets }\end{array}$} & \multicolumn{4}{c}{ Cecum activity } \\
\cline { 2 - 5 } & $\begin{array}{l}\text { Cecum } \\
\text { wt. (g) }\end{array}$ & $\begin{array}{c}\text { TVFA's } \\
(\mathbf{m g} / \mathbf{1 0 0 m})\end{array} \begin{array}{c}\text { Ammonia-N } \\
(\mathbf{m g} / \mathbf{1 0 0 m})\end{array}$ & $\mathbf{p H}$ \\
\hline G1 & $96.71^{\mathrm{ab}}$ & 20.75 & 24.92 & $7.80^{\mathrm{ab}}$ \\
G2 & $80.00^{\mathrm{b}}$ & 22.13 & 25.38 & $7.90^{\mathrm{a}}$ \\
G3 & $107.76^{\mathrm{a}}$ & 22.00 & 28.85 & $7.60^{\mathrm{ab}}$ \\
G4 & $91.72^{\mathrm{ab}}$ & 22.75 & 28.18 & $7.64^{\mathrm{ab}}$ \\
G5 & $94.49^{\mathrm{ab}}$ & 26.50 & 28.14 & $7.58^{\mathrm{ab}}$ \\
G6 & $85.00^{\mathrm{ab}}$ & 27.50 & 28.77 & $7.61^{\mathrm{ab}}$ \\
G7 & $89.38^{\mathrm{ab}}$ & 27.00 & 27.52 & $7.45^{\mathrm{b}}$ \\
G8 & $77.47^{\mathrm{b}}$ & 26.75 & 28.12 & $7.47^{\mathrm{b}}$ \\
\pm SE & \pm 8.29 & \pm 2.58 & \pm 1.92 & \pm 0.108 \\
\hline
\end{tabular}

$a$ and $b$ means in the same column with different superscripts are significantly $(\mathrm{P} \leq 0.05)$ different. $\mathrm{SE}=$ standard error

Table 10. Economic efficiency as affected by dried taro waste and dried yeast in the experimental diets for growing NZW rabbits.

\begin{tabular}{lcccccccc}
\hline \multirow{2}{*}{ Item } & \multicolumn{9}{c}{ Experimental diets } & \multicolumn{1}{c}{ G6 } & G7 & G8 \\
\cline { 2 - 9 } & G1 & G2 & G3 & G4 & G5 & G6 & 2.22 \\
Price / kg diet (L.E) & 2.67 & 2.70 & 2.50 & 2.54 & 2.34 & 2.37 & 2.18 & 2.22 \\
Total feed intake/rabbit (gm) & 5295.3 & 5336.0 & 5293.2 & 5300.8 & 5285.0 & 5299.7 & 5266.6 & 5325.2 \\
Total feed cost/rabbit (L.E) & 14.14 & 14.42 & 13.24 & 13.46 & 12.36 & 12.58 & 11.46 & 11.84 \\
Total weight gain/rabbit (gm) & 1364.3 & 1396.8 & 1366.5 & 1371.2 & 1321.3 & 1333.4 & 1341.6 & 1280.8 \\
Feed cost/ kg gain (L.E) & 10.36 & 10.33 & 9.69 & 9.81 & 9.35 & 9.43 & 8.54 & 9.24 \\
Total revenue/rabbit (L.E) & 40.93 & 41.90 & 40.99 & 41.14 & 39.64 & 40.00 & 40.25 & 38.42 \\
Net revenue/rabbit (L.E) & 26.79 & 27.48 & 27.76 & 27.68 & 27.28 & 27.42 & 28.78 & 26.59 \\
Economic efficiency (E.EF) & 1.89 & 1.91 & 2.10 & 2.06 & 2.21 & 2.18 & 2.51 & 2.25 \\
Relative E. EF\% & 100 & 100.6 & 110.7 & 108.6 & 116.5 & 115.1 & 132.5 & 118.6 \\
\hline
\end{tabular}

Based on prices of the Egyptian market during the experimental period (2016).

The price of one ton of clover hay $(12 \% \mathrm{CP})$, barley, yellow corn, soybean meal $(44 \% \mathrm{CP})$, wheat bran, molasses, methionine, vitamins\& minerals mix., salt, lime stone and Di-calcium phosphate were 1900, 2400, 2300, 4550, 1970, 1900, 60000, 11000, 500,500 and 1500 LE, respectively. Prices of one ton taro waste, yeast and body weight on selling were 200, 12000 and $30 \mathrm{LE}$, respectively. Initial price of rabbit $25 \mathrm{LE}$. Net revenue / rabbit $(\mathrm{LE})=($ Total revenue / rabbit $(\mathrm{LE}))-($ Total feed cost $/$ rabbit $(\mathrm{LE}))$. Economic efficiency $=($ Net revenue/rabbit $(\mathrm{LE})) /($ Total feed cost/rabbit (LE). Feed cost $/ \mathrm{kg}$ gain $=$ Total feed cost/rabbit $(\mathrm{LE}) * 1000 /$ Total weight gain/rabbit $(\mathrm{gm})$.

\section{CONCLUSION}

In conclusion, dried taro waste (TW) could be used in feeding of growing rabbits up to $22.5 \%$ without or with dried yeast (DY, $0.5 \%$ ) of the diet with no adverse effect on productive performance, carcass traits, physiological function and economic efficiency.

\section{REFERENCES}

Abang, F.B. and H.A. Shittu (2015). Effect of fermentation on the chemical composition of peeled taro cocoyam meal (Colocasia esculenta var esculenta). IOSR J. of Agric. and Veterinary Sci., volume 8, Issue 3 Ver. II: 2319-2380, www.iosrjournals.org.

Abdou, Aziza M. and A.M. Gomaa (2002). Pelleted diet enrichment with a yeast culture (Saccharomyces cerevisiae) and its impact on growth, carcass traits and caecal microbial content of growing New Zealand White rabbits. Egyptian J. of Applied Sci., 17 (5): 18-30.
Abdulrashid, M. and L.N. Agwunobi (2009). Taro cocoyam (Colocasia esculenta) meal as feed ingredient in poultry. Pakistan J. of Nutrition, 8: 668-673.

Abou-Raya, A.K. (1967). Animal and Poultry Nutrition. Dar-El-Maarif, Cairo, (Arabic Text book).

Adejoro, F.A., T.I. Ijadunola, O.M. Odetola and B.A. Omoniyi (2013). Effect of sundried, soaked and cooked wild cocoyam (Colocasia esculenta) meal on the growth performance and carcass characteristics of broilers. Livestock Research for Rural Development, 25 (6):1-7.

Agriculture Ministry Decree (1996). The Standard Properties for Ingredients, Feed Additives and Feed Manufactured for Animal and Poultry. El- Wakaee.

Agwunobi, L.N., P.O. Angwukan, O.O. Cora and M.A. Isika (2002). Studies of the use of Colocasia esculenta (Taro cocoyam) in the diets of weaned pigs. Tropical Animal Health and Production. 34 (3): 241-247. 
Anigbogu, N.M. (1996). Economic costs of using taro (Colocasia esculenta Linn). In broiler rations. ITTA Tropical Root and Tuber Crops Bulletin, 9 (1): $8-10$.

A.O.A.C. (1996). Official Methods of Analysis, Association of Official Analytical Chemists. $16^{\text {th }}$ edition, Washington, USA.

Bakory, M.T.A. (2014). Yeast culture in animal nutrition: A review. Bioscience Research, 11(1): 10-19.

Belhassen T., A. Bonai, Z.S. Gerencsér, Z.S. Matics, T. Tuboly, R. Bergaoui and M. Kovacs (2016). Effect of diet supplementation with live yeast saccharomyces cerevisiae on growth performance, caecal ecosystem and health of growing rabbits. World Rabbit Sci., 24: 191-200.

Cheeke, P.R. (1987). Rabbit Feeding and Nutrition. Academic Press. Orlando, Florida, U.S.A.

Conway, E.J. (1958). Micro-diffusion analysis and volumetric error $\left(4^{\text {th }}\right.$ Ed.). The McMillan Co., New York.

Dahlgren, E.M. and G.P. Savage (2007). Reduction in oxalate content during the preparation of a traditional Tongan dessert. Journal of Food, Agriculture \& Environment, 5 (3\&4): 29.

Duncan, D.B. (1955). Multiple range and multiple F-Test. Biometrics, 1:42.

Du Thanh Hang, Than Thi Thanh Tra, Nguyen Thi Loc, Phan Vu Hai, Nguyen Dang Qui, Ha Le Ngoc Linh and Le Duc Ngoan (2014). Taro (Colocasia esculenta (L) schott) and banana pseudo-stem as energy sources for pigs in Central Vietnam. Livestock Research for Rural Development, 26 (6), ISSN 0121-3784.

Eadie, J.M., P.N. Hobson and S.O. Mann (1967). A note on some comparisons between the rumen content of barley fed steers and that of young calves also fed on high concentrate rations. J. Anim. Prod., 9: 247.

Eggum, B.O. (1989). Biochemical and methodological principles. In: Bock, H.D., B.O. Eggum, A.G. Low, O. Simon, T. Zebrowska (Eds), Protein Metabolism in Farm Animals. Evaluation, Digestion, Absorption, and metabolism. Oxford Science Publications, Deutscher Landwirtscafts Verlag, Berlin, pp.1-52.

FAO (1993). FAOSTAT. Food and Agricultural Organization of the United Nations.

Fekete, S.G., K. Fodor, A. Bersenyi, Z. Zoldag and A. Chwalibog (2001). Effect of feeding level on body composition and sexual maturity of female rabbits. Proceedings of $15^{\text {th }}$ symposium on energy metabolism in animals. Snekkersten, Denmark, pp. 377-380.

Fernandez, C., A. Cobos and M.J. Fraga (1994). Effect of fat inclusion on diet digestibility in growing rabbits. J. Animal Sci., 72: 1508-1518.

Hammad, M.R. and A.M. Gomaa (2001). Influence of supplying mash diet with a probiotic yeast culture on growth performance and caecal microbial content of New Zealand White rabbits. Egyptian Journal of Applied Science, 16 (11): 1-10.
Hang, D.T. and T.R. Preston (2010). Effect of processing Taro leaves on oxalate concentrations and using the ensiled leaves as a protein source in pig diets in central Vietnam. Livest. Res. Rural Dev., 22 (4): 68.

Ismail, F.S.A., M.H. Rabie and A.E. Abd El-Khalek (2004). Effects of some sources of yeast cultures as feed additives on growth performance of New Zealand White rabbits. Egyptian J. of Rabbit Sci., 14 (2): 101-116.

Jouany, J.P. and D.P. Morgavi (2007). Use of 'natural' products as alternatives to antibiotic feed additives in ruminant production. Animal, 1 (10): 1443-1466.

Khanna, S., H.K. Gulati, A.K. Verma, S.S. Sihag, D.P. Sharma and P.K. Kapoor (2014). Effect of yeast supplementation and alternative housing systems on performance of rabbits. Haryana Vet., 53 (1): 23-27.

Makled, M.N. (1991). The potentials of probiotics in poultry feed. A review $3^{\text {rd }}$ Scientific Symp. for Animal Poultry and Fish Nutrition, Sakha, Kafr-ELSheikh, Egypt, pp. 54-68.

Manal, K. Abou El-Naga (2012). Effect of dietary yeast supplementation on broiler performance. Egypt. Poult. Sci., 32 (1): 95-106.

Michael, W.D. (2005). Saponin. The Florida State University.

http://micro.magnet.fsu.edu/phytochemicals/pages/s aponin.html.

Miles, R.D. and S.M. Bootwella (1991). Direct feed microbial in animal production. National Feed Ingredients Association, Desmonres, Iowa, USA.

Ministry of Agriculture (2016). Bulletin of the Agricultural Statistics, part (2) summer \& nili crops, 2014/2015, pp. 203.

MOA (2001). Feed Composition Tables for Animal and Poultry Feedstuff Used in Egypt. Technical Bulletin No.1, Central Lab for Feed and Food, Ministry of Agriculture, Egypt.

Ngo Huu Toan and T.R. Preston (2010). Taro as a local feed resource for pigs in small scale household condition. Livest. Res. Rural Dev., 22 (8).

Nguyen Tuyet Giang, T.R. Preston and B. Ogle (2010). Effect on the performance of common ducks of supplementing rice polishings with taro (Colocacia esculenta) foliage. Livestock Research for Rural Development, 22 (10): 194.

North, M.O. (1981). Commercial Chicken Production Manual. 3rd Ed, Avi., Publishing Company. I.N.C. Westport Connecticut, USA.

Ojokoh, A.O. (2007). Effect of fermentation on the chemical composition of mango (Mangifera indica) peels. African Journal of Biotechnology, 6 (6): 1979-1981.

Olajide, R. (2012). Growth performance, carcass, haematology and serum metabolites of broilers as affected by contents of anti-nutritional factors in soaked wild cocoyam (Colocasia esculenta (l.) schott) corm-based diets. Asian J. of Anim. Sci., 6: 23-32. 
Onifade, A.A. and O.A. Abu, (1998). Productive response of rabbits to supplemental copper in a diet based on tropical feedstuffs. J. Appl. Anim. Res., 13: 129135.

Onifade, A.A., A.A. Odunsi, G.M. Babatunde, B.R. Olorede and E. Muma (1999). Comparison of the supplemental effects of Saccharomyces cerevisiae and antibiotics in low protein and high fibre diets fed to broiler chickens. Archives of Animal Nutrition, 52 (1): 29-39.

Paryard, A. and M. Mahmoudi (2008). Effect of different levels of supplemental yeast (Saccharomyces cerevisiae) on performance, blood constituents and carcass characteristics of broiler chicks. J. African Agric. Res., 3 (12): 835842.

Ravindran, V., R. Sivakanesan and H.W. Cyril (1996). Nutritive value of raw and processed colocasia (Colocasia esculenta) corm meal for poultry. Animal Feed Sci. \& Technology, 57 (4): 335-345.

Renard, C. (2001). Crop residues in mixed crop/livestock farming systems. CAB International in association with the association with the International Crops Research Institute for the Semi-Arid Tropics and the International Livestock Research Institute. Pp. 25-36.
SAS Institute Inc., (2004). SAS/STAT 9.1 User's Guide: Statistics, SAS Institute Inc., Cary, N.C., USA.

Soliman, A.Z.M., R.I. El-Kady, A.A. El-Shahat and M.Z. Sedik (2000). Effect of some commercial growth promoters on the growth performance and caecum microbiology of growing New Zealand White rabbits. Egyptian Journal of Rabbit Science, 10 (2): 239-252

Stanley, V.G., R. Ojo, S. Woldesenet, D.H. Hutchinson and L.F. Kubena (1993). The use of saccharomyces cerevisiae to suppress the effects of alfatoxicosis in broiler chicks. Poultry Science, 72: $1867-1872$

Ukpabi, U.J. and J.I. Ejidoh (1989). Effect of deep oil frying on the oxalate content and the degree of itching of cocoyams (Xanthosoma and colocassia spp). Technical paper presented at the $5^{\text {th }}$ Annual Conference of the Agriculture Society of Nigeria, Federal University of Technology, Owerri, Nigeria, 3- 6 (September).

Wikipedia, the free encyclopedia. http://en. wikipedia. org/wiki/Taro.

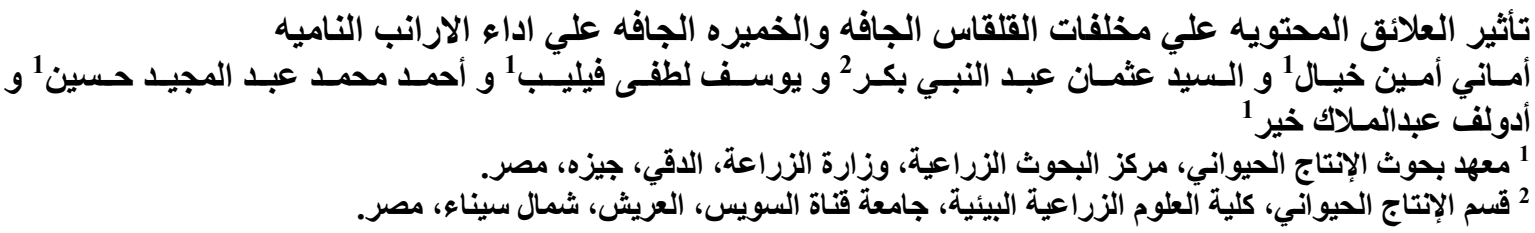

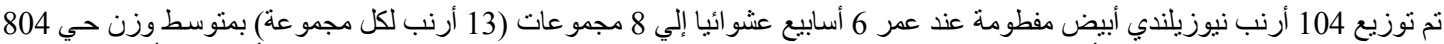



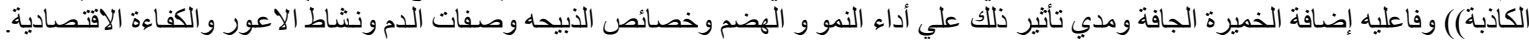

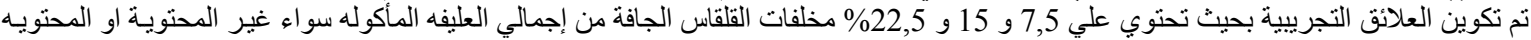

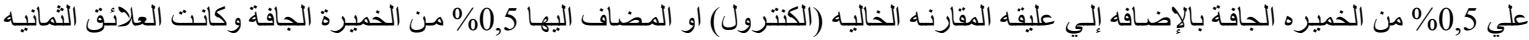

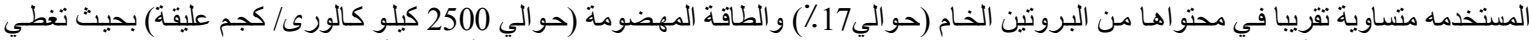

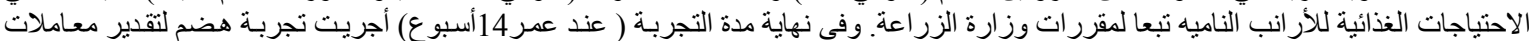

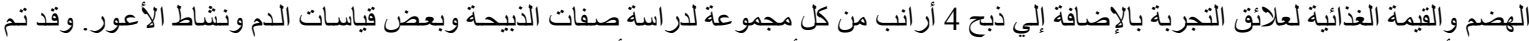

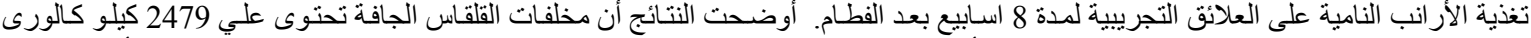

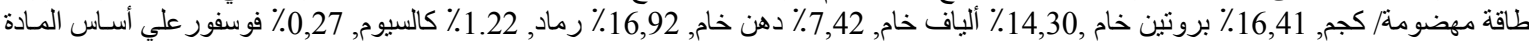

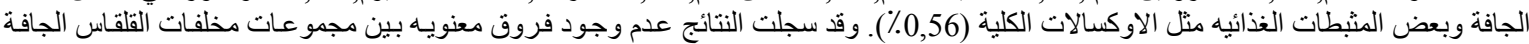



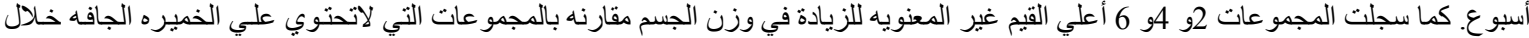

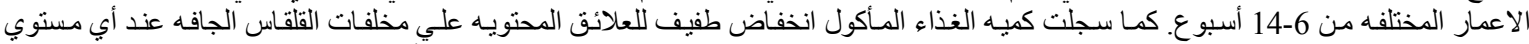



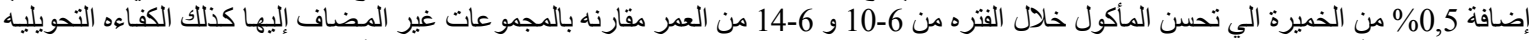

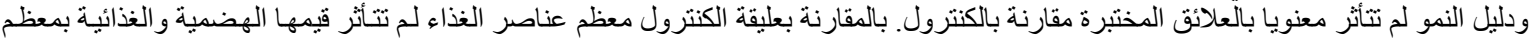

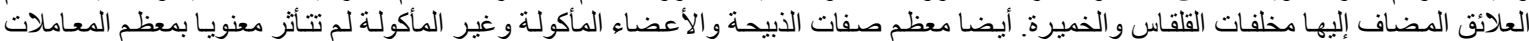

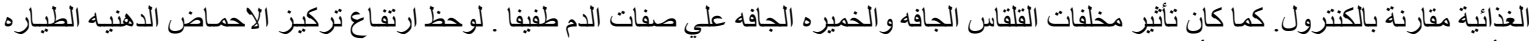



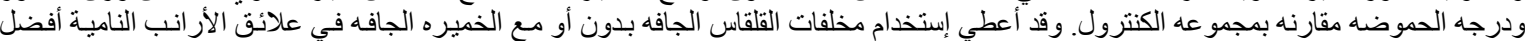

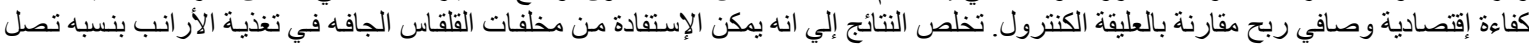

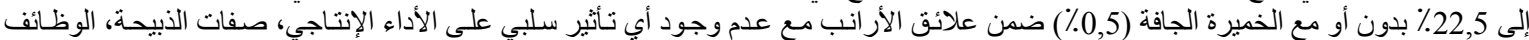
الفسيولوجية والكفاءة الاقتصادية. 